\title{
Nocardia takedensis sp. nov., isolated from moat sediment and scumming activated sludge
}

\author{
Hideki Yamamura, ${ }^{1}$ Masayuki Hayakawa, ${ }^{1}$ Youji Nakagawa, ${ }^{1}$ \\ Tomohiko Tamura, ${ }^{2}$ Tetsuro Kohno, ${ }^{3}$ Fumio Komatsu ${ }^{4}$ and Yuzuru limura ${ }^{1}$ \\ ${ }^{1,3}$ Division of Applied Biological Sciences ${ }^{1}$ and Department of Civil and Environmental \\ Engineering ${ }^{3}$, Interdisciplinary Graduate School of Medicine and Engineering, University \\ of Yamanashi, Takeda-4, Kofu 400-8511, Japan \\ ${ }^{2}$ NITE Biological Resource Center, Department of Biotechnology, National Institute of \\ Technology and Evaluation, Kazusakamatari 2-5-8, Kisarazu 292-0818, Japan \\ ${ }^{4}$ Water Quality Control Laboratory, Nihon Hels Industry Corporation, Higashigoken-cho 3-25, \\ Shinjuku-ku, Tokyo 162-0813, Japan
}

Correspondence

Masayuki Hayakawa

hayakawa@ab11.yamanashi.ac.jp

\begin{abstract}
Chemotaxonomic and morphological characterization of two actinomycete strains, MS1-3 ${ }^{\top}$ and AS4-2, respectively isolated from moat sediment and scumming activated sludge, was carried out. This characterization clearly demonstrated that strains MS1-3 ${ }^{\top}$ and AS4-2 belong to the genus Nocardia. 16S rRNA gene sequencing studies showed that these isolates are most closely related to Nocardia beijingensis (98.1-98.3\% similarity), Nocardia brasiliensis (97.9-98.0\%) and Nocardia tenerifensis (97-8-97.9\%). However, the results of DNA-DNA hybridizations and physiological and biochemical tests showed that strains MS1-3' and AS4-2 could be differentiated from their closest phylogenetic relatives both genotypically and phenotypically. It is proposed that the two isolates be classified as representatives of a novel species of Nocardia, Nocardia takedensis sp. nov. The type strain is MS1-3 ${ }^{\top}$ (=NBRC $\left.100417^{\top}=\mathrm{DSM} 44801^{\top}\right) ;$ AS4-2 (=NBRC $\left.100418=\mathrm{DSM} 44802\right)$ is a reference strain.
\end{abstract}

The genus Nocardia Trevisan 1889 belongs to the suborder Corynebacterineae (Stackebrandt et al., 1997) and currently encompasses about 40 species of mycolic-acid-containing actinomycetes, including the recently described species Nocardia puris, Nocardia inohanensis, Nocardia yamanashiensis, Nocardia tenerifensis and Nocardia neocaledoniensis (Yassin et al., 2003; Kageyama et al., 2004; Kämpfer et al., 2004; Saintpierre-Bonaccio et al., 2004).

The Nocardia selective isolation method utilizing sucrose density-gradient centrifugation was developed previously (Yamamura et al., 2003a). Using this technique, two Nocardia strains, MS1-3 ${ }^{\mathrm{T}}$ and AS4-2, were isolated. $\mathrm{MS1} 1-3^{\mathrm{T}}$ was from a sediment sample taken from the moat surrounding Takeda Shrine in Yamanashi Prefecture, Japan, and AS4-2 was from a scumming activated sludge obtained from a

Published online ahead of print on 10 September 2004 as DOI 10.1099/ijs.0.63189-0.

Abbreviation: $A_{2}$ pm, diaminopimelic acid.

The GenBank/EMBL/DDBJ accession numbers for the 16S rRNA gene sequences of Nocardia takedensis $\mathrm{MS}^{-} 3^{\top}$ and $\mathrm{AS} 4-2$ are AB158277 and AB158278.

SEMs of cells of strain MS1-3 ${ }^{\top}$ and an extended phylogenetic tree derived from 16S rRNA gene sequences are available as supplementary material in IJSEM Online. sewage treatment plant in Saitama Prefecture, Japan (Yamamura et al., 2003b, 2004). These isolates could be differentiated from all known species of Nocardia in terms of their 16S rRNA gene restriction fragment length polymorphism (RFLP) patterns (Yamamura et al., 2003b). The aim of present study was to determine the taxonomic position of isolates MS1-3 ${ }^{\mathrm{T}}$ and AS4-2 using a polyphasic approach.

Colony morphology and micromorphological properties of strains MS1-3 $3^{\mathrm{T}}$ and AS4-2 were observed by light and scanning electron microscopy according to a previously described procedure (Hayakawa et al., 1996). Physiological and biochemical properties were recorded according to well-established procedures (Gordon et al., 1974; Isik et al., 1999). Diaminopimelic acid $\left(\mathrm{A}_{2} \mathrm{pm}\right)$ isomers and sugars in whole-cell hydrolysates were analysed based on the methods established by Hasegawa et al. (1983) and Schaal (1985), respectively. Standard procedures were also used for extraction and analysis of mycolic acids (Schaal, 1985), fatty acids (Tamura et al., 1994) and isoprenoid quinones and polar lipids (Minnikin et al., 1984), and compared to the appropriate controls. Genomic DNA was prepared as described by Torres et al. (1996). The G + C contents of DNA from the isolates were determined by HPLC, as described by Tamura et al. (1994). DNA-DNA hybridization was carried out as described by Kusunoki et al. (1991) using biotinylated DNA. 
$16 \mathrm{~S}$ rRNA genes were amplified by PCR and sequenced following procedures described previously (Yamamura et al., 2003a). The 16S rRNA gene sequences obtained in the present study were manually aligned with sequences of available from EMBL/GenBank/DDBJ. A phylogenetic tree was inferred using neighbour-joining tree-making algorithms (Saitou \& Nei, 1987). The program CLUSTAL W (Thompson et al., 1994) was used to calculate evolutionary distances and similarity values. Topography of the constructed tree was evaluated by bootstrap analysis with 1000 replicates (Felsenstein, 1985).

Chemotaxonomic and morphological characteristics of isolates MS1-3 $3^{\mathrm{T}}$ and AS4-2 were consistent with their assignment to the genus Nocardia (Goodfellow, 1998; Goodfellow et al., 1999). Whole-cell hydrolysates of the test strains were rich in meso- $\mathrm{A}_{2} \mathrm{pm}$, arabinose and galactose (wall chemotype IV sensu Lechevalier \& Lechevalier, 1970). The predominant menaquinone component was $\mathrm{MK}-8\left(\mathrm{H}_{4}, \omega\right.$-cycl. $)$. They also contained phosphatidylethanolamine (phospholipid type PII sensu Lechevalier et al., 1977). In addition, TLC revealed that the strains contained methyl mycolates, which are equivalent in mobility to nocardomycolic acid. $\mathrm{C}_{16: 0}$, cis-9 $\mathrm{C}_{18: 1}$ and 10-methyl $\mathrm{C}_{16: 0}$ were present as major cellular fatty acids. Microscopic observation confirmed the formation of branched substrate hyphae, fragmenting into rod-shaped elements (Goodfellow \& Lechevalier, 1989), and relatively short aerial hyphae with chains of arthrospores (see Supplementary Fig. A in IJSEM Online).

Almost complete 16S rRNA gene sequences (1345 nt) of isolates MS1-3 ${ }^{\mathrm{T}}$ and AS4-2 were compared with sequences of recognized species of Nocardia. The 16S rRNA gene sequences of the test strains and those representative of the genus Nocardia had $95 \cdot 3-98 \cdot 3 \%$ similarity. Highest sequence similarities were shown with Nocardia beijingensis (98.1-98.3\%), Nocardia brasiliensis $(97 \cdot 9-98 \cdot 0 \%)$ and $N$. tenerifensis $(97 \cdot 8-97 \cdot 9 \%)$. The $16 \mathrm{~S}$ rRNA gene-based tree, constructed using the neighbour-joining method, showed that the test strains formed a monophyletic clade that is loosely associated with $N$. brasiliensis, $N$. tenerifensis and Nocardia transvalensis (Fig. 1). The taxonomic integrity of the test strains was supported by DNA relatedness data. Strain MS1-3 ${ }^{\mathrm{T}}$ showed DNA relatedness values of $8 \cdot 1-23 \cdot 1 \%$ to $N$. beijingensis, $N$. brasiliensis and N. tenerifensis, results that were well below the $70 \%$ cut-off point recommended for assignment of bacterial strains to the same genomic species (Wayne et al., 1987). On the other hand, the 16S rRNA gene sequence similarity between MS1 $-3^{\mathrm{T}}$ and AS4-2 was $99 \cdot 8 \%$ and the DNA relatedness value was $91.0 \%$. The phenotypic properties of these two strains also clearly distinguished them from representatives of $N$. beijingensis, $N$. brasiliensis, $N$. tenerifensis and $N$. transvalensis (Table 1).

Based on 16S rRNA gene sequence data, DNA-DNA hybridization studies and biochemical properties, as well as on RFLP patterns (Yamamura et al., 2003b), it is proposed that strains MS1- $3^{\mathrm{T}}$ and AS4-2 represent a novel species in the

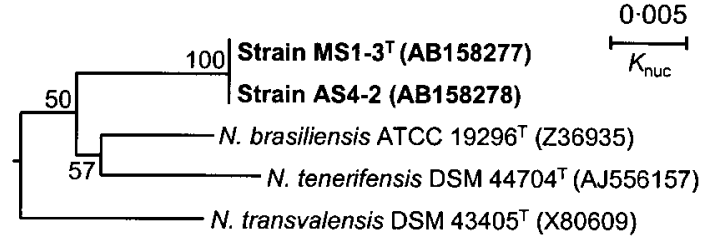

Fig. 1. Phylogenetic tree derived from $16 \mathrm{~S}$ rRNA gene sequences showing the relationship of strains $M S 1-3^{T}$ and AS4-2 to the nearest Nocardia species. The tree was constructed using the neighbour-joining method and $K_{\text {nuc }}$ values (Saitou \& Nei, 1987). Only values above $50 \%$ significance are indicated. A tree based on available 16S rRNA gene sequences of all Nocardia species is available as Supplementary Fig. B in IJSEM Online.

Table 1. Phenotypic properties that differentiate strains MS1 $-3^{\top}$ and AS4-2 from representatives of phylogenetically related Nocardia species

Strains: 1, MS1- $3^{\mathrm{T}}$ and AS4-2; 2, N. beijingensis IFO (now NBRC) $16342^{\mathrm{T}}$; 3, N. brasiliensis ATCC $19296^{\mathrm{T}} ; 4, N$. tenerifensis DSM $44704^{\mathrm{T}}$; 5, N. transvalensis DSM $43405^{\mathrm{T}}$. ND, Not determined; +, positive; -, negative; W, weak reaction. Data for reference strains were taken from Goodfellow \& Lechevalier (1989), Wang et al. (2001), Yassin et al. (2003) and Kämpfer et al. (2004).

\begin{tabular}{|c|c|c|c|c|c|}
\hline Character & 1 & 2 & 3 & 4 & 5 \\
\hline Aesculin hydrolysis & + & + & + & + & - \\
\hline \multicolumn{6}{|l|}{ Decomposition of: } \\
\hline Casein & - & - & + & + & - \\
\hline Elastin & - & - & + & ND & - \\
\hline Hypoxanthine & - & - & + & + & - \\
\hline Tyrosine & - & - & + & + & - \\
\hline Uric acid & + & - & - & $\mathrm{ND}$ & ND \\
\hline Xanthine & - & + & - & - & - \\
\hline \multicolumn{6}{|c|}{ Growth on sole carbon sources: } \\
\hline Adonitol & - & - & - & - & + \\
\hline L-Arabinose & - & + & - & $\mathrm{ND}$ & - \\
\hline Cellobiose & - & + & - & $\mathrm{ND}$ & - \\
\hline D-Fructose & - & + & + & - & ND \\
\hline meso-Erythritol & - & + & - & ND & + \\
\hline meso-Inositol & - & - & + & + & - \\
\hline D-Mannitol & - & + & + & + & - \\
\hline D-Mannose & + & + & - & ND & + \\
\hline Raffinose & - & + & - & ND & - \\
\hline L-Rhamnose & - & + & - & - & + \\
\hline D-Sorbitol & - & + & - & - & - \\
\hline D-Trehalose & - & + & + & + & + \\
\hline D-Xylose & - & + & - & $\mathrm{ND}$ & - \\
\hline Isoamyl alcohol & - & - & $\mathrm{W}$ & $\mathrm{ND}$ & + \\
\hline Citrate & - & + & + & + & + \\
\hline p-Hydroxybenzoic acid & - & + & - & + & - \\
\hline Growth at $45^{\circ} \mathrm{C}$ & - & - & + & - & - \\
\hline
\end{tabular}


genus Nocardia. The name Nocardia takedensis sp. nov. is proposed for these two strains.

\section{Description of Nocardia takedensis sp. nov.}

Nocardia takedensis (ta.ke.den'sis. N.L. fem. adj. takedensis pertaining to the Takeda Shrine, from where the organism was first isolated).

Aerobic, Gram-positive, non-motile actinomycete. Forms an orange substrate and white aerial mycelium, which fragments into rod-shaped elements. Diffusible pigments are not produced. Aesculin and urea are hydrolysed and nitrate is reduced. Does not degrade adenine, casein, elastin, hypoxanthine, tyrosine or xanthine, but does degrade uric acid. Grows well at $30^{\circ} \mathrm{C}$, but does not grow at $45^{\circ} \mathrm{C}$. Assimilates 2,3-butanediol, D-galactose, D-glucose, D-mannose, sucrose (all at $1 \%, \mathrm{w} / \mathrm{v})$ and acetate (at $0 \cdot 1 \%, \mathrm{w} / \mathrm{v})$ as sole carbon sources, but not adonitol, L-arabinose, cellobiose, Dfructose, meso-erythritol, meso-inositol, isoamyl alcohol, D-mannitol, D-melezitose, D-melibiose, 1,2-propanediol, raffinose, L-rhamnose, D-sorbitol, D-trehalose, D-xylose (at $1 \%, \mathrm{w} / \mathrm{v}$ ), adipic acid, citrate, D-gluconate, $m$-hydroxybenzoic acid, $p$-hydroxybenzoic acid, pimelic acid or sebacic acid $($ at $0 \cdot 1 \%, \mathrm{w} / \mathrm{v})$. The major cellular fatty acids are $\mathrm{C}_{16: 0}(45 \cdot 0 \%)$, cis-9 $\mathrm{C}_{18: 1}(20 \cdot 4 \%)$ and 10-methyl $\mathrm{C}_{18: 0}$ $(10 \cdot 4 \%)$. The $\mathrm{G}+\mathrm{C}$ content of the DNA is $68 \cdot 6 \mathrm{~mol} \%$.

The type strain is $\mathrm{MS} 1-3^{\mathrm{T}}\left(=\mathrm{NBRC} 100417^{\mathrm{T}}=\mathrm{DSM}\right.$ $44801^{\mathrm{T}}$ ), isolated from a sediment sample taken from the moat surrounding Takeda Shrine in Yamanashi Prefecture, Japan.

\section{Acknowledgements}

We thank Professor Dr Hans G. Trüper, Institut für Mikrobiologie und Biotechnologie, Rheinische Friedrich-Wilhelm-Universität Bonn, for his helpful suggestions regarding the bacterial nomenclature. Appreciation is also given to Miss Y. Ishikawa for technical assistance.

\section{References}

Felsenstein, J. (1985). Confidence limits on phylogenies: an approach using the bootstrap. Evolution 39, 783-791.

Goodfellow, M. (1998). Nocardia and related genera. In Topley and Wilson's Microbiology and Microbial Infections, 9th edn, vol. 2, Systematic Bacteriology, pp. 463-489. Edited by A. Balows \& B. I. Duerden. London: Arnold.

Goodfellow, M. \& Lechevalier, M. P. (1989). Genus Nocardia Trevisan 1889. In Bergey's Manual of Systematic Bacteriology, vol. 4, pp. 2350-2361. Edited by S. T. Williams, M. E. Sharpe \& J. P. Holt. Baltimore: Williams \& Wilkins.

Goodfellow, M., Isik, K. \& Yates, E. (1999). Actinomycete systematics: an unfinished synthesis. Nova Acta Leopold NF80 (312), 47-82.

Gordon, R. E., Barnett, D. A., Handerhan, J. E. \& Pang, C. H.-N. (1974). Nocardia coeliaca, Nocardia autotrophica, and the nocardin strain. Int J Syst Bacteriol 24, 54-63.

Hasegawa, T., Takizawa, M. \& Tanida, S. (1983). A rapid analysis for chemical grouping of aerobic actinomycetes. J Gen Appl Microbiol 29, 319-322.
Hayakawa, M., Takeuchi, T. \& Toyohiko, Y. (1996). Combined use of trimethoprim with nalidixic acid for the selective isolation and enumeration of actinomycetes from soil. Actinomycetologica 10, 80-90.

Isik, K., Chun, J., Hah, Y. C. \& Goodfellow, M. (1999). Nocardia salmonicida nom. rev., a fish pathogen. Int J Syst Bacteriol 49, 833-837.

Kageyama, A., Yazawa, K., Nishimura, K. \& Mikami, Y. (2004). Nocardia inohanensis sp. nov., Nocardia yamanashiensis sp. nov. and Nocardia niigatensis sp. nov., isolated from clinical specimens. Int J Syst Evol Microbiol 54, 563-569.

Kämpfer, P., Buczolits, S., Jäckel, U., Grün-Wollny, I. \& Busse, H.-J. (2004). Nocardia tenerifensis sp. nov. Int J Syst Evol Microbiol 54, 381-383.

Kusunoki, S., Ezaki, T., Tamesada, S., Hatanaka, Y., Asano, K., Hashimoto, Y. \& Yabuuchi, E. (1991). Application of colorimetric microdilution plate hybridization for rapid genetic identification of 22 Mycobacterium species. J Clin Microbiol 29, 1596-1603.

Lechevalier, M. P. \& Lechevalier, H. (1970). Chemical composition as a criterion in the classification of aerobic actinomycetes. Int J Syst Bacteriol 20, 435-443.

Lechevalier, M. P., De Bièvre, C. \& Lechevalier, H. A. (1977). Chemotaxonomy of aerobic actinomycetes: phospholipid composition. Biochem Syst Ecol 5, 249-260.

Minnikin, D. E., O’Donnell, A. G., Goodfellow, M., Alderson, G., Athalye, M., Schaal, K. \& Parlett, J. H. (1984). An integrated procedure for the extraction of bacterial isoprenoid quinones and polar lipids. J Microbiol Methods 2, 233-241.

Saintpierre-Bonaccio, D., Maldonado, L. A., Amir, H., Pineau, R. \& Goodfellow, M. (2004). Nocardia neocaledoniensis sp. nov., a novel actinomycete isolated from New-Caledonian brown hypermagnesian ultramafic soil. Int J Syst Evol Microbiol 54, 599-603.

Saitou, N. \& Nei, M. (1987). The neighbor-joining method: a new method for reconstructing phylogenetic trees. Mol Biol Evol 4, 406-425.

Schaal, K. P. (1985). Identification of clinically significant actinomycetes and related bacteria using chemical techniques. In Chemical Methods Bacterial Systematics, pp. 359-381. Edited by M. Goodfellow \& D. E. Minnikin. London: Academic Press.

Stackebrandt, E., Rainey, F. A. \& Ward-Rainey, N. L. (1997). Proposal for a new hierarchic classification system, Actinobacteria classis nov. Int J Syst Bacteriol 47, 479-491.

Tamura, T., Nakagaito, Y., Nishii, T., Hasegawa, T., Stackebrandt, E. \& Yokota, A. (1994). A new genus of the order Actinomycetales, Couchioplanes gen. nov., with descriptions of Couchioplanes caeruleus (Horan and Brodsky 1986) comb. nov. and Couchioplanes caeruleus subsp. azureus subsp. nov. Int J Syst Bacteriol 44, 193-203.

Thompson, J. D., Higgins, D. G. \& Gibson, T. J. (1994). CLUSTAL W: improving the sensitivity of progressive multiple sequence alignment through sequence weighting, position-specific gap penalties and weight matrix choice. Nucleic Acids Res 22, 4673-4680.

Torres, R. D., Oletta, C. A. \& Zlotnik, H. (1996). A rapid and gentle method for isolation of genomic DNA from pathogenic Nocardia spp. Clin Diagn Lab Immunol 3, 601-604.

Wang, L., Zhang, Y., Lu, Z., Shi, Y., Liu, Z., Maldonado, L. \& Goodfellow, M. (2001). Nocardia beijingensis sp. nov., a novel isolate from soil. Int J Syst Evol Microbiol 51, 1783-1788.

Wayne, L. G., Brenner, D. J., Colwell, R. R. \& 9 other authors (1987). International Committee on Systematic Bacteriology. Report of the ad hoc committee on reconciliation of approaches to bacterial systematics. Int J Syst Bacteriol 37, 463-464. 
Yamamura, H., Hayakawa, M. \& limura, Y. (2003a). Application of sucrose-gradient centrifugation for selective isolation of Nocardia spp. from soil. J Appl Microbiol 95, 677-685.

Yamamura, H., Hayakawa, M., Nakagawa, Y. \& limura, Y. (2003b). Species diversity of nocardiae isolated from lake and moat sediment samples. Actinomycetologica 17, 44-46.
Yamamura, H., Hayakawa, M., Nakagawa, Y. \& limura, Y. (2004). Characterization of Nocardia asteroides isolates from different ecological habitats on the basis of repetitive extragenic palindromic-PCR fingerprinting. Appl Environ Microbiol 70, 3149-3151.

Yassin, A. F., Sträubler, B., Schumann, P. \& Schaal, K. P. (2003). Nocardia puris sp. nov. Int J Syst Evol Microbiol 53, 1595-1599. 